\title{
The changing role of collecting societies in the internet
}

\author{
Sebastian Haunss \\ Research Center on Inequality and Social Policy, University of Bremen, Germany, \\ sebastian.haunss@sfb597.uni-bremen.de
}

Published on 30 Sep 2013 | DOI: 10.14763/2013.3.199

\begin{abstract}
Collecting societies currently face major challenges stemming from: the reconfiguration of existing and emergence of new powerful players in the field of music distribution; the necessity of cross-territorial licensing options, and; the fragmentation of copyrights. This article presents an overview of recent technical and policy developments in this area in Europe and, on a more abstract level, it discusses structural problems underlying the policy conflicts.
\end{abstract}

Keywords: Copyright, License, Intermediaries, Music, Distribution, Intellectual property rights, Collecting societies, European Union

\section{Article information}

Received: 27 Aug 2013 Reviewed: 12 Sep 2013 Published: 30 Sep 2013

Licence: Creative Commons Attribution 3.0 Germany

Competing interests: The author has declared that no competing interests exist that have influenced

the text.

URL: http://policyreview.info/articles/analysis/changing-role-collecting-societies-internet

Citation: Haunss, S. (2013). The changing role of collecting societies in the internet. Internet Policy Review, 2(3). https://doi.org/10.14763/2013.3.199

Collecting societies currently face major challenges stemming from: the reconfiguration of existing and emergence of new powerful players in the field of music distribution; the necessity of cross-territorial licensing options, and; the fragmentation of copyrights. This article presents an overview of recent technical and policy developments in this area in Europe and, on a more abstract level, it discusses structural problems underlying the policy conflicts.

Collecting societies became indispensable intermediaries in the copyright system of the 20th century. Their core task was the collection of high-volume, low-value royalties stemming from secondary uses (e.g., broadcasting, public performance, lending) of creative works. Collecting societies are the solution to the problems that the individual creator - provided she/he is not among the small group of famous, top-selling artists - is confronted with, such as a weak bargaining position vis-à-vis broadcasters or online music platforms, and the fact that transaction costs for collecting small royalties from many users of her/his work (e.g., bars, clubs, discotheques) are generally too high (Mazziotti et al. 2009: $17 \mathrm{ff}$ ). 
In the field of music, the system of national collecting societies with monopolistic or quasi monopolistic positions always had its shortcomings. They are usually privileging top-selling artists and are not well suited to accommodate non-commercial music production and venues. But they provided a relatively stable and reliable framework for licensing musical works. As a result of the growing importance of the internet for the distribution and sale of music, this system of national collective rights management societies currently faces major challenges. The internet introduces new and transnational distribution channels. In combination with the heavily criticised (Drexl et al. 2012) attempts of the European Commission to introduce more competitive elements to the management of copyrights for musical works in the online environment, commentators describe the current state of the system as "uncertain and complex" (Hilty \& Nérisson 2013).

For the average internet user, these developments usually only become visible when, for example, YouTube videos of musical performances become unavailable in Germany while users in the USA or Great Britain can view them without restrictions. But even in the reporting on the highly publicised conflict between YouTube/Google and the German collecting society for musical works (GEMA, Gesellschaft für musikalische Aufführungs- und mechanische Vervielfältigungsrechte) the relationship between this conflict and the more general changes of the copyright system is usually not mentioned. In this overview-article, I will take the GEMAYoutube case as a starting point to discuss the above mentioned major challenges to the current system of collective copyright management: (1) the reconfiguration of existing and the emergence of new powerful players in the field of music distribution, (2) the necessity of crossterritorial licensing options, and (3) the fragmentation of copyrights.

\section{THE GEMA-YOUTUBE CASE}

According to a study by OpenDataCity (OpenDataCity 2013), over 60 \% of the world's top 1000 YouTube videos are currently not available to internet users in Germany, because Google, YouTube's holding company, and GEMA, the German collecting society for musical works, have been unable to come to an agreement regarding the copyrighted music embedded in these videos (Wragge 2012). While Google is willing to pay for a blanket license for GEMA's catalog with a lump sum or possibly a fixed percentage of its advertising revenues generated on the site where the videos are displayed, GEMA is demanding a minimum payment of 0.375 cent per streamed video. Google is thus essentially asking for a contract that is similar to the current agreement between GEMA and radio stations, where radio stations pay a fixed percentage of their revenues. GEMA, instead, wants to treat YouTube more like a producer of recorded media, who has to pay GEMA a fixed minimum sum per sold CD, vinyl disc of audio cassette.1 In other countries, Google has reached agreements with collecting societies, but the terms of these agreements are unknown because Google insists on very strict non-disclosure agreements. According to research from Spreeblick blogger Johnny Haeusler, the amount YouTube is paying the British collecting society PRS is probably 30 times lower than what GEMA demands (Haeusler 2011), and Helienne Lindvall reports in The Guardian that artists under the current agreements are actually receiving only minimal royalties of less than US\$ 10 for one million YouTube streams (Lindvall 2012), which is more that 500 times less than what GEMA demands.

The conflict between GEMA and YouTube goes back to 2009 when an initial agreement between the two parties expired.2 Since then, GEMA has twice tried to sue YouTube for copyright infringement and was partially successful after the copyright chamber of the regional court in Hamburg ruled in April 2012 that YouTube has an indirect liability ("Störerhaftung”) to remove 
infringing content once it has been made aware of it. Also, the judgement reads, it has the duty to prevent, in an automated process, future uploads of the same musical content (LG Hamburg 2012). Whereas YouTube had argued that, as a hosting provider, it would not be liable for the content its users are uploading, the court thus upheld that YouTube has an active duty to prevent the uploading of copyright infringing content.

Currently, without an agreement on the amount of royalties, Google uses its high visibility of YouTube to build pressure on GEMA towards an agreement by blocking potentially infringing videos in Germany and instead displaying a message stating "This video is not available in Germany, because it possibly contains music for which the necessary rights have not been granted by GEMA. We are sorry for that". In return, GEMA has again turned to the courts and is seeking an injunction against YouTube at the regional court in Munich, arguing that these displays would be cheap propaganda and misleading the public in its negative perception of GEMA.

On the surface the conflict between GEMA and YouTube/Google is a conflict about the appropriate amount of royalties: Two powerful players try to use their bargaining powers to maximize their respective profits (or in the case of GEMA their members' profits). Below the surface the conflict is an indicator of three important changes which will alter the existing copyright system: The emergence of new distribution channels, the dysfunctionality of territorial borders in the virtual world, and the fragmentation of copyright licenses.

\section{NEW DISTRIBUTION CHANNELS}

Since the triumph of radio in the 1930 s the distribution channels for music remained for most of the 2oth century in their core structure unchanged. Music was broadcasted through the radio, performed in public (live or in the form of recordings) and sold as vinyl records and later as CDs. One important change was the emergence of music videos, but in terms of distribution technology they essentially represent just another form of broadcasting that didn't add anything new to the radio broadcasting model. Collecting societies have developed rather well working models for these distribution channels (Kretschmer, Klimis, and Wallis 1999).

Music streaming on the internet now has introduced a new mode of distribution that differs significantly from the traditional distribution channels. Like radio, music television or public performances, it offers only temporary access to the musical work.3 But unlike traditional performances or broadcasting it is not the artist or radio station that selects the music but the individual user, who can also stop and "rewind" the stream as often as s/he likes. In this sense streaming is much more like selecting music from a personal record or CD collection, only that the streamed music is not owned by the listener. So far collecting societies are still struggling with this new distribution channel. They behave in the usual way of incumbents by trying to subsume new developments under the already established practices. Trying to use the established business model for the new distribution channel, GEMA thus treats streams like low value mp3 file sales which are in turn treated like the production of CDs or vinyl records. But because in contrast to CDs or mp3 files only temporary copies are transmitted that do not stay with the user it is far from obvious that offering streams would be essentially the same thing as making CDs or selling mp3 files. Therefore new powerful entrants in the field of music distribution like Google/YouTube or Apple can try to use their economic power to establish a different interpretation - one that is more favorable to their business interests. This option is not available for small start-ups who instead have to accept the market power of the collecting 
societies.

The changing distribution technologies that go along with the entrant of new powerful players and conflicts of interpretation destabilize the existing system of collective copyrights management. This is amplified by the activities of major music publishers, who see the current restructuring as an opportunity to opt out of the collective copyright management system to administer the licensing of their high value top selling repertoire themselves.

\section{TERRITORIAL BORDERS IN THE VIRTUAL WORLD}

Another factor that sets the current copyright management system in motion is the contradiction between national copyright systems and the global reach of the internet. In the age of physical goods and local performances national collecting societies have developed a system of mutual treaties that allows them to license the repertoires of rights-owners from other countries for their respective territory. This territorial system is not well suited to handle a situation where internet users are in principle able to access content on the web irrespective of their own geographical position or the content's physical location. The current "solution" for this incompatibility has not been an adaptation of the nation-state based copyright system but a rather imperfect technical fix that grants selective access to copyright-protected content depending on the IP address of the computer by which its physical location is determined. This technical fix has in turn created a whole business of VPN tunnel and proxy services that offer their customers tailored "national" IP addresses by routing the internet traffic through their company servers, so that the destination website "sees" only the IP address of the VPN or proxy service provider. A German customer then, for example, appears to come the US, and is then able to buy video and music streaming services which are not available in her home country due to territorial copyright restrictions.

In Europe, where the European Union was founded with the aim to create a single European market, this territorial fragmentation is especially virulent. The European Commission thus has addressed the problem of territorial fragmentation of copyrights in several initiatives. Starting with its 2005 regulation on collective cross-border management of copyright, the Commission has tried to enable online services to obtain pan-European licenses for musical works (Commission Recommendation 2005). But the effect was so far mainly legal uncertainty and a strengthening of the position of the major Anglo-american recording companies which withdrew their performance rights for online services from the repertoires managed by the national collecting societies (Hilty \& Nérisson 2013). Currently a proposal for a directive that addresses the issue of pan-European licensing (Proposal for a Directive of the European parliament 2012) is on its way through the European decision-making process. It has already received similar criticism like the 2005 regulation (Drexl et al. 2012; COMMUNIA 2013). It remains to be seen whether the substantial changes that have been requested by the Council and the ongoing debates in the European Parliament will amend it (Humeau 2013), so that it can effectively tackle the problem of territorial fragmentation of copyrights and at the same time strike a balance that is acceptable for the various interests involved.

\section{FRAGMENTATION OF LICENSES}

As already mentioned, the attempts to enable cross-territorial licensing for online music services 
show a side-effect of license fragmentation. This is partly due to the Commission's regulation that enables rights-holders to withdraw specific rights for online use from the bundle of rights that has so far been handled by the national collecting societies. And it is partly a result of different legal frameworks in the Anglo-american and continental European countries: Whereas collecting societies in continental European countries usually manage both the "mechanical rights" that govern the reproduction of music in the form of records, CDs or mp3 files, and the "performance rights" that govern live performances and broadcasting, the Anglo-american performance rights organizations usually manage only "performance rights". The result of cross-territorial licenses is that it now becomes increasingly uncertain which rights for which use an organization can grant.

This trend will probably be further exacerbated by the desire of more powerful rights-holders (large recording companies, top-selling artists) to skip the intermediary and manage the licenses themselves (Tschmuck 2009). The internet enables individual firms to better monitor the online use of music for which it has the copyrights, and lowers the transactions costs that made collecting societies such an attractive option.

License fragmentation is also promoted by a growing trend among musicians to provide selected songs or even relevant parts of their repertoire under non-exclusive open content licenses. The most often used Creative Commons license allows for example use and copying only for noncommercial purposes. This makes licensing more difficult because it introduces an additional factor that now determines whether or not royalties should be collected for the use of a musical work. Only few collecting societies have so far adapted their rules to allow artists the use of open content licenses (Buma/Stemra in the Netherlands, KODA in Denmark, and SACEM in France). In Germany the reluctance or GEMA to accommodate open content licenses has led to the project to establish an alternative collecting society, the "Cultural Commons Collecting Society" with an explicit focus on Creative Commons and other free licenses (Kleinz 2013).

\section{THE FUTURE OF COLLECTIVE LICENSE MANAGEMENT}

It is clear that the internet has profoundly altered and will continue to change the way music is made available, used and consumed. As a result we already have seen significant changes to the system in which royalties for the use of musical works are collected and re-distributed. The internet has created opportunities for new powerful players like Google or Apple who try to shift the established balance between rights-owners, intermediaries, distributers, and users of musical works. But the current legal battles about the scope of licenses and the responsibilities of content and/or hosting providers is not just the result of shifting market powers. It is also an indicator of the limits of core concepts, which form the foundation of the existing copyright system. The idea of a territory, the notion of a physical copy, the act of broadcasting: These concepts have to be at least partially re-defined in the virtual realm of the internet.

The GEMA-YouTube conflict thus goes much deeper than the notion that is for example voiced in the tech-blog techdirt, of a "predatory and overbearing" (Cushing 2013) collecting society that tries to extract overblown rates from users of its repertoire and to block technological change. The conflict reflects the instability of a system that was established under different conditions. It is now experiencing the emergence of new practices, actor coalitions, and claims, and various stakeholders and political actors are currently intervening - with conflicting ideas of how it should evolve. 
Possible development paths are: (1) A consolidation and concentration process in Europe where the big collecting societies from Germany and the UK extend their reach beyond the national borders - a scenario that would fit the Commission's ideas of "harmonization" and competition in the internal market. (2) A (partial) replacement scenario, where internet giants try to create their own collecting society to compete with the existing collecting societies. Such a move would be similar to the US National Association of Broadcasters' strategy to create in 1939 Broadcast Music, Inc. (BMI) to compete with the then dominant American Society of Composers, Authors and Publishers (ASCAP). (3) Or a fragmentation scenario, where collecting societies will increasingly represent only partial repertoires and selected uses and where niche markets emerge for example for open licenses.

\section{FOOTNOTES}

1. See tariffs at

https://www.gema.de/fileadmin/user_upload/Musiknutzer/Tarife/Tarife_vra/tarif_vr_t_h1.p df

2.: A detailed analysis of the conflict with background information and interviews with representatives of both sides is available [in German] on the iRights.Info blog at http://irights.info/worber-gema-und-youtube-streiten.

3. At least if the stream is not downloaded, which is the modern equivalent to tape-recording of radio broadcasts or public performances. 


\section{REFERENCES}

Commission Recommendation 2012/0180 on collective cross-border management of copyright and related rights for legitimate online music services. (2005) OJ L276/54-57.

Proposal for a Directive of the European parliament and of the Council on collective management of copyright and related rights and multi-territorial licensing of rights in musical works for online uses in the internal market. (2012) COM(2012)372. Retrieved from http://ec.europa.eu/internal_market/copyright/docs/management/com-2012-3722_en.pdf

COMMUNIA (2013). COMMUNIA policy paper on the Directive proposal on Collective Management of Copyright. Brussels: COMMUNIA Association on the Digital Public Domain. Retrieved from

http://www.communia-association.org/wp-content/uploads/2013/o1/communia_policy_pape r_colsoc_directive.pdf

Cushing, T. (2013). How GEMA Is (Still) The Worst "Collective Rights" Organization In The World. techdirt. Retrieved from

https://www.techdirt.com/articles/20130425/17042522839/how-gema-is-still-worst-collective -rights-organization-world.shtml

Drexl, J. et al. (2012). Comments of the Max Planck Institute for Intellectual Property and Competition Law on the Proposal for a Directive of the European Parliament and of the Council on collective management of copyright and related rights and multi-territorial licensing of rights in musical works for online uses in the internal market COM (2012)372, Munich: Max Planck Institute for Intellectual Property and Competition Law. Retrieved from http://ssrn.com/abstract=2208971

Haeusler, J. (2011). GEMA vs. YouTube: Gerüchte, Zahlen, Forderungen. Spreeblick. Retrieved from http://www.spreeblick.com/2011/o6/21/gema-vs-youtube-geruchte-zahlen-forderungen/

Hilty, R. \& Nérisson, S. (2013). Collective Copyright Management and Digitization: The European Experience. In: Towse, R. \& Handke, C. (eds.) (2013). Handbook of the Digital Creative Economy, Cheltenham: Edward Elgar.

Humeau, M. (2013). Unanimous JURI vote on Collective Rights Management directive. EDRigram. Retrieved from

http://www.edri.org/edrigram/number11.14/JURI-vote-collective-rights-management

Kleinz, T. (2013). NRW-Förderung für Projekt der GEMA-Alternative C3S. heise online. Retrieved from

http://www.heise.de/newsticker/meldung/NRW-Foerderung-fuer-Projekt-der-GEMA-Alternati ve-C3S-1936471.html?view=print

Kretschmer, M., Klimis, G.M. \& Wallis, R. (1999). The Changing Location of Intellectual Property Rights in Music: A Study of Music Publishers, Collecting Societies and Media Conglomerates. Prometheus 17(2): 163-186.

Lindvall, H. (2012). Music streaming: what do songwriters really get from YouTube or Pandora?. The Guardian. Retrieved from

http://www.theguardian.com/media/2012/oct/10/music-streaming-songwriters-youtube-pand ora 
LG Hamburg (2012). Urteil vom 20. April 2012. Az. 310 O 461/10

Mazziotti, G. et al. (2009). Collecting Societies and Cultural Diversity in the Music Sector. Brussels: European Parliament, Policy Department Structural and Cohesion Policies. Retrieved from http://works.bepress.com/mazziotti/10

OpenDataCity (2013). GEMA versus YouTube's Top 1000. Berlin. Retrieved from http://apps.opendatacity.de/gema-vs-youtube/en/

Tschmuck, P. (2009). Copyright, Contracts and Music Production. Information, Communication \& Society 12(2): 251-266.

Wragge, A. (2012). Worüber GEMA und Youtube streiten, iRights.info. Retrieved from http://irights.info/worber-gema-und-youtube-streiten 